Institute of

Public Finance
NEWSLETTER

AN OGGASIONAL PUBLIGATION OF THE INSTITUTE OF PUBLIG FINANGE

\title{
What will happen to state aid in Croatia after EU accession?
}

MARINA KESNER-ŠKREB Institut za javne financije

\section{INTRODUCTION AND SUMMARY}

As Croatia is less than a year away from EU accession, it is interesting to analyse what has been negotiated in the area of state aid, i.e. what adjustments the country will have to make with in this respect. An analysis of state aid development in the EU-I2 Member States, which joined the EU in 2004 and 2007 (Jović, 20I2), allows us to draw some parallels with Croatia, and indicates that we are obviously confronted with numerous reforms in this area. This is also suggested by the long-time stagnation in state aid in the country. Hence, urgent reforms are called for.

The main findings of the analysis of state aid in Croatia are the following:

- There were no significant changes in Croatian state aid during the 2002-IO period: the share of state aid in GDP continued to be among the largest in Europe, and the structure of aid remained almost unchanged throughout the period, with a dominant share of sectoral aid, notably aid to the shipbuilding and transport sectors, which only suggests that no major structural economic reforms have taken place.

- Following its uneven movements over the 2002-Io period, total state aidr in Croatia is still 2.4 times higher than that in EU-I2 (I.2\% vs. 0.5\% of GDP).

- Since 2002, aid to agriculture and fisheries has continually increased from HRK I.7 billion to HRK 4 billion (in 2OIO), while sectoral aid reached record highs during election years.

- Shipbuilding was the absolute record holder, with HRK I3 billion of aid received from 2002 to 20IO, followed by tran-

I State aid less agriculture, fisheries and transport. sport with HRK IO.4 billion, the bulk of which went to Croatian Railways.

- Under the Treaty Concerning the Accession of the Republic of Croatia to the EU (hereinafter: Accession Treaty), the following has been agreed with regard to state aid:

- if shipyards are not restructured and privatised before EU accession, i.e. in case the conditions agreed upon under the Accession Treaty are not met, the European Commission may order Croatia to recover any rescue and restructuring aid (plus compound interest), granted to them since I March 2006;

- if Sisak Ironworks fails to reimburse state aid in the amount of HRK I9 million, it will be obliged to reimburse any rescue and restructuring aid (plus compound interest), granted to it since I March 2006;

- seven aid measures constitute "existing aid", which the Commission can examine, but cannot order their reimbursement; Croatia has applied for another four aid measures to be included in this list.

- The approaching of the accession date has accelerated the restructuring of the shipbuilding, steel and railway sectors, because state aid reforms in future member states have been in the forefront of the EU's attention.

- Upon Croatia's accession, state aid will be transferred to the jurisdiction of the European Commission, which will grant and supervise aid according to the same procedure as the one applicable in all other Member States. State aid will continue to be granted in Croatia according to the same rules as those currently followed by the Croatian Competition Agency (CCA). 


\section{SIZE AND STRUGTURE OF STATE AID IN GROATIA} UNTIL 2010

State aid in Croatia still stands considerably above the EU levels ${ }^{2}$. While the EU-27 Member States allocated 0.5\% of GDP for aid to enterprises in 20IO, Croatia allocated 2.4 times more (I.2\% of GDP3) for this purpose. Hardly more favourable is the comparison between the levels of aid in Croatia and in new Member States (EU-I2): in 20IO, the share of state aid in GDP in Croatia (I.2\%) was twice as large as in EU-I2 (0.6\%). However, there are considerable differences in this respect across the new Member States: in Bulgaria, state aid accounts for 0.04\% of GDP, in Czech Republic, Poland, Slovenia and Malta over 0.5\%. Hungary has the largest share of aid in GDP, I.94\%, which makes this country the absolute record holder in state aid allocation among both the new Member States and EU-27 as a whole. Had Croatia been a Member State in 20Io, it would the time horizon is too narrow and the sample period of two election years too short for taking any firm conclusions on the influence of politics on economic events, this coincidence was still very interesting. After the elections and record highs reached in 2003 and 2007, the share of total state aid in GDP declined during the next two years.

The next election year was 20II (not yet included in the official data published by the CCA), and it is interesting to see whether the state aid movements confirmed the above mentioned estimates, i.e. whether state aid continued its growth from 20IO. The election year 2OII, when state aid at best stagnated, was followed by 20I2, the last year before EU accession. The experience of the new EU Member States, which markedly increased state aid in the pre-

\section{Chart I}

State aid-to-GDP ratios in EU and Croatia*, 2010

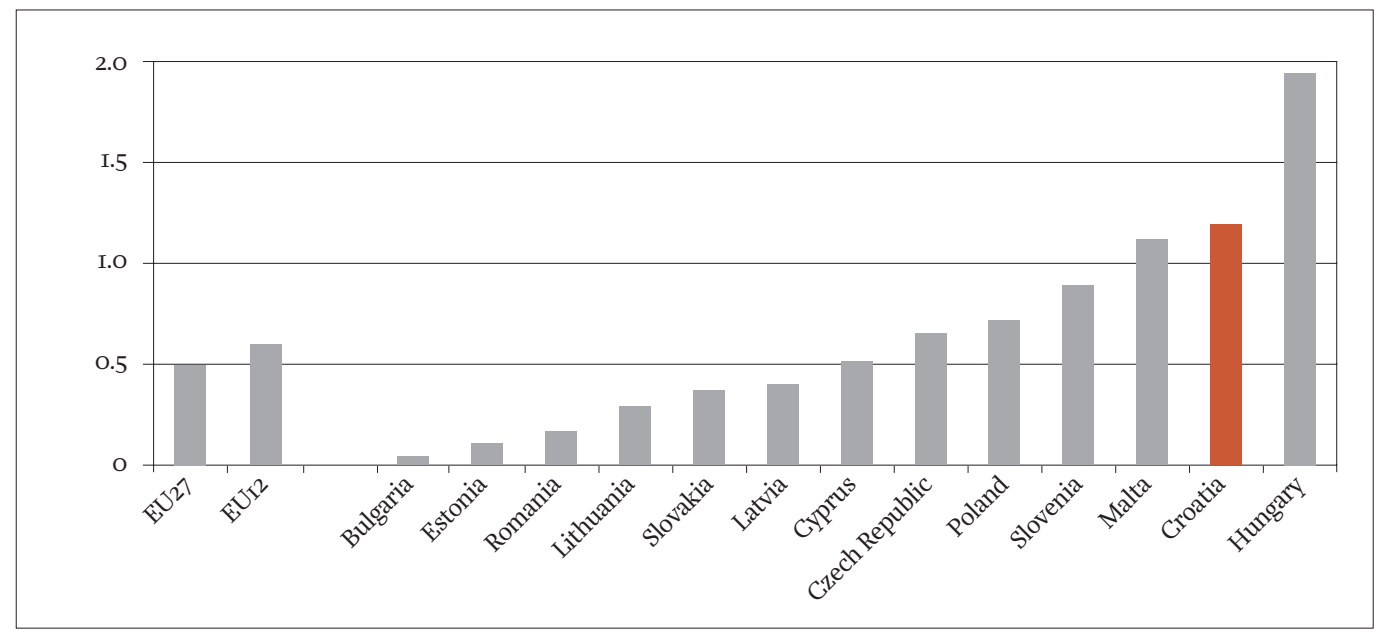

*State aid less agriculture, fisheries and transport

Source: CCA (2OII)

have been the second largest provider of aid to enterprises in the EU after Hungary.

The growth path of Croatia's state aid towards such high shares in GDP was far from linear. The share of total aid in GDP during the 2002-IO period (Chart 2) clearly shows uneven dynamics, i.e. alternation between periods of its growth and periods of its decline. It is interesting to note that growth in the share of aid in GDP was due to political movements in the country, so that it reached its peak in 2003 and 2007, the years of parliamentary elections and the formation of new Parliamentary Assemblies. While

2 The analysis of Croatian state aid is based on the Croatian Competition Agency's (CCA) annual state aid reports.

3 State aid less agriculture, fisheries and transport. accession years, suggests that in Croatia as well, state aid will not stop growing until accession.

Movements in the share of total state aid in GDP are heavily influenced by sectoral aid movements. The almost identical curves of total aid and sectoral aid during the entire sample period clearly show how strongly the total aid movements depend on sectoral aid. This is understandable, given that sectoral aid accounted for the bulk of total aid provided during the entire 2002-Io period (Table I).

Another specificity worth noting is the trend in aid to agriculture and fisheries. Instead of following the sectoral aid movements, aid to agriculture has continuously grown, almost independently from other economic con- 


\section{Chart 2}

Movements in state aid-to-GDP ratio in Croatia, 2002-IO

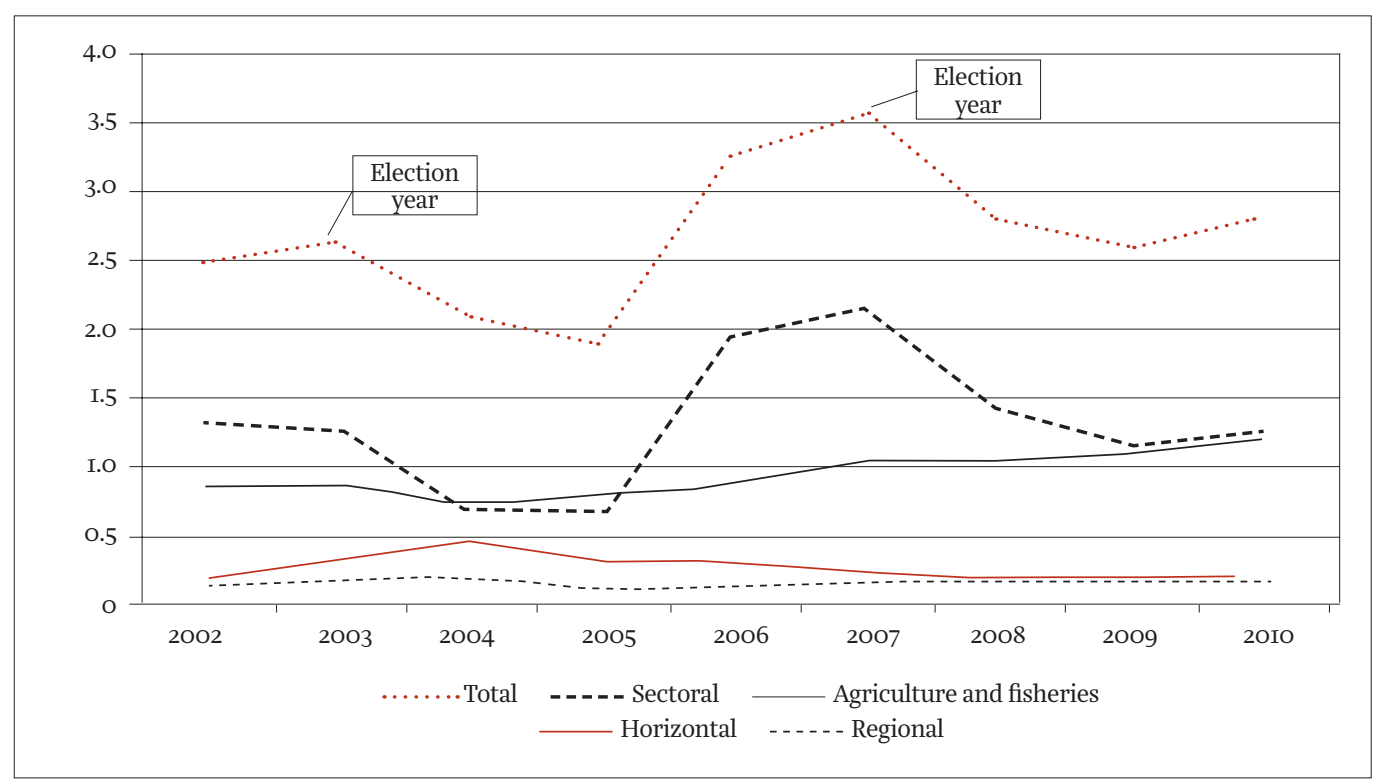

Source: CCA (2OII)

ditions, whereas its share in GDP almost doubled after 2004 (from $0.7 \%$ in 2004 to $1.2 \%$ in 2OIO). Pursuant to current regulations, the CCA neither supervises nor closely monitors aid to agriculture, so that the Agency's reports only provide data on the total amounts of this aid, and no detailed information. Hence, this analysis only points out

\section{Table I}

State aid (less agriculture) by category, 2002-IO

\begin{tabular}{|c|c|c|c|c|c|}
\hline \multirow[b]{2}{*}{ Category } & \multicolumn{2}{|c|}{ 2002-10 } & \multicolumn{3}{|c|}{2010} \\
\hline & $\begin{array}{c}\text { million } \\
\text { HRK }\end{array}$ & $\begin{array}{c}\text { Share in } \\
\text { total aid (\%) }\end{array}$ & $\begin{array}{c}\text { million } \\
\text { HRK }\end{array}$ & $\begin{array}{c}\text { Share in } \\
\text { total aid }(\%)\end{array}$ & $\begin{array}{c}\text { Share in total aid } \\
\text { (less transport) }(\%)\end{array}$ \\
\hline Horizontal aid & 6,733 & 15.0 & 636 & II. 8 & 16.5 \\
\hline Employment & 2,207 & 4.9 & 93 & $\mathrm{I} .7$ & 2.4 \\
\hline $\mathrm{R} \& \mathrm{D}$ & I,097 & 2.4 & I67 & 3.I & 4.4 \\
\hline SMEs & $\mathrm{I}, \mathrm{O} 25$ & 2.3 & $\mathrm{I70}$ & 3.2 & 4.4 \\
\hline Other objectives & 980 & 2.2 & $\mathrm{n} / \mathrm{a}$ & 0.0 & 0.0 \\
\hline Training & 660 & I.5 & 48 & 0.9 & $\mathrm{I} .2$ \\
\hline Culture & 404 & 0.9 & $5 \mathrm{I}$ & I.O & I.3 \\
\hline $\begin{array}{l}\text { Environmental protection and } \\
\text { energy saving }\end{array}$ & I86 & 0.4 & 27 & 0.5 & 0.7 \\
\hline Supporting access to finance in the crisis & $\mathrm{I} 7 \mathrm{I}$ & 0.4 & 78 & I.5 & 2.0 \\
\hline Sectoral aid & 34,286 & 76.I & $4, \mathrm{I} 45$ & 77.I & 68.1 \\
\hline Shipbuilding & 13,083 & 29.1 & $\mathrm{I}, 244$ & 23.I & 32.3 \\
\hline Transport & IO,434 & 23.2 & $\mathrm{I}, 524$ & 28.4 & 0.0 \\
\hline Radio and television broadcasting & 5,356 & II.9 & $\mathrm{I}, \mathrm{I} 82$ & 22.0 & 30.7 \\
\hline Rescue and restructuring & 2,361 & 5.2 & 27 & 0.5 & 0.7 \\
\hline Tourism & $\mathrm{I}, 479$ & 3.3 & 157 & 2.9 & 4.I \\
\hline Other sectors & 917 & 2.0 & 8 & 0.2 & 0.2 \\
\hline Financial services & 402 & 0.9 & $\mathrm{n} / \mathrm{a}$ & 0.0 & 0.0 \\
\hline Steel production & $25 \mathrm{I}$ & 0.6 & $\mathrm{O}$ & 0.0 & 0.0 \\
\hline Regional aid & $4, \mathrm{OI} 4$ & 8.9 & 593 & II.O & I5.4 \\
\hline TOTAL & 45,034 & IOO.O & 5,374 & IOO.O & IOO.O \\
\hline
\end{tabular}

$n / a-$ not available

Source: CCA (2OII) 
to this steady upward trend, without going into any details about supporting agriculture.

Furthermore, it is worrying that the share of horizontal aid intended for all enterprises and not only for selected sectors or enterprises, in GDP has declines continuously. This aid is allocated for research and development, small and medium-sized enterprises, environmental protection professional training, employment, etc., and its objective is to correct market failures and thus stimulate economic growth, encourage competition and contribute to the overall economic prosperity of the country. The share of this aid stood at $0.5 \%$ of GDP in 2004, but halved to only $0.2 \%$ of GDP in 2010.

What were the objectives for which the bulk of public funds were spent during the nine-year period? Sectoral aid was the dominating government's industrial policy instrument throughout the sample period, accounting for over $76 \%$ of total aid, while horizontal aid participated with as little as $15 \%$ in the total.

As expected, shipbuilding was the record holder in sectoral aid, having received HRK I3 billion, followed by transport (HRK Io billion, mostly granted to Croatian Railways) and radio and television broadcasting (HRK 5 billion).

As concerns horizontal aid, the bulk of funds were allocated for employment incentives (HRK 2.2 billion), followed by R\&D and small and medium-sized enterprises (HRK I billion each). Environmental protection and energy saving were no major concerns for government's aid policy: with only HRK I87 million of aid received, they almost brought up the rear on the list of horizontal aid recipients.

If 20Io, the last year of the sample period, is singled out in the analysis, no significant changes can be observed. Specifically, horizontal aid did not increase and its share in total aid even dropped by 3.2 percentage points (from $15 \%$ to II.8\%) relative to the entire reference period, suggesting that the state aid policy still did not undergo any fundamental structural reforms. This was confirmed by movements in sectoral aid, the share of which in total aid even increased by one percentage point in 2010 relative to the entire period, from $76.1 \%$ to $77.1 \%$.

On the other hand, a comparison of the state aid structures in 20Io between Croatia and EU-27 shows that Croatia has to make a tremendous effort to carry out the necessary structural reforms of its economy. To be specific, while in 20IO, sectoral aid accounted for $15 \%$ of total aid in EU-27, its share in Croatia exceeded $68 \%^{4}$ of total aid (less

4 The data in column 5 of Table i have been prepared for a compari- transport), i. e. it was 4.5 times larger. Horizontal aid (including regional aid) in EU-27 accounted for as much as $85 \%$ of total aid, almost three times more than in Croatia (32\% of total aid less transport).

\section{STATE AID IN THE TREATY GONGERNING THE AGGESSION OF GROATIA TO THE EUROPEAN UNION}

As suggested by the above analysis, Croatia made no significant progress in the area of state aid during the nineyear period under review, which clearly shows that no major structural economic reforms were carried out. In 2OIO, the share of state aid in GDP was one of the largest in Europe, while the structure of aid remained almost unchanged throughout the period, with sectoral aid having a dominant share, especially in the shipbuilding and transport sectors.

The EU accession is expected to bring about substantial changes: the size of aid should finally be reduced and its structure should change in favour of horizontal rather than sectoral aid. The state aid control should be taken over by the European Commission.

The Accession Treaty determines that Croatia has assumed the EU acquis communautaire and specifies the terms of its membership. The Accession Treaty provisions governing market competition also include conditions for state aid allocation, relating to the obligations assumed by Croatia with respect to the restructuring of the shipbuilding and steel sectors and the definition of existing aid. Below is a brief presentation of the obligations assumed with respect to these areas 5 .

\section{SHIPBUILDING}

Under the Accession Treaty, Croatia has agreed to carry out the privatisation and restructuring of the following shipbuilding companies: 3. Maj, Brodotrogir, Brodosplit, Brodogradilište specijalnih objekata - Split and Brodogradilište Kraljevica. Interested buyers have submitted their restructuring plans that have been accepted by the CCA and the European Commission, and will be incorporated in the respective privatisation contracts concluded between Croatia and the buyers of these companies. The conditions to be respected in the restructuring process are the following:

- The contribution to the restructuring plan to be provided by the companies from own resources must represent at least $40 \%$ of the total restructuring costs. All state aid received by

son between the shares of aid in total aid (less transport), as is done in the EU statistics. In the calculation of the shares of individual aid in total aid (less transport), regional aid is added to horizontal aid in the said statistics. The same has been done in this paper (European Commission, 2012c).

5 The provisions of the Accession Treaty are set out in italics. 
the shipbuilding companies since I March 2006 shall be considered as restructuring aid.

- The overall production capacity of the yards must be reduced compared to the levels of I June $201 \mathrm{I}$ from $47 \mathrm{I} 324$ CGT to 372346 CGT, i.e. by 2I\%, no later than I year from the date of signing the privatisation contract. Capacity reduction shall be implemented through a permanent closure of slipways, through the designation of slipways for military production in accordance with Treaty on the Functioning of the European Union and/or through surface area reduction.

- The total annual production of all the companies shall be limited to 323600 CGT for a ten-year period, starting on I January 20II. Within this amount, the limits for each company are accurately specified. The companies shall not receive any new rescue or restructuring aid before at least Io years have elapsed since the date of signing the privatisation contract. The privatisation contracts shall be signed and submitted to the Commission for acceptance before Croatia's accession to the EU on I July 2013.

Should these commitments not be fulfilled, after the accession, the European Commission may order Croatia to recover any rescue aid, including compound interest, granted to a company since I March 2006.

The Commission shall monitor the implementation of the restructuring plans and the compliance with the conditions set out in the Accession Treaty, particularly regarding the amounts of state aid, own contribution, capacity reductions and the measures aimed at ensuring a return to viability. Croatia shall submit reports to the Commission, which will monitor the restructuring of the shipbuilding companies until the end of 2020. ${ }^{6}$

The abovementioned conditions for the restructuring of shipbuilding companies are not specific to Croatia only, but are laid down in the Rules on State Aid for Rescue and Restructuring 7 , that constitute an integral part of the EU acquis and apply to all undertakings in the EU territory. The Rules generally envisage compensation measures for reducing capacity and output, as well as own contributions of undertakings undergoing restructuring, and they have been elaborated for Croatia in its Accession Treaty.

The purpose of compensation measures is to minimise the negative effects of aid on trading conditions. If an enterprise receives aid, its presence in the market must be limited, because otherwise that enterprise would be in a much more favourable market position compared to an enterprise that has not received aid. In such a case, market competition would be distorted, and such aid would be

6 An abstract of Annex VIII to the Accession Treaty.

7 Croatia has accepted these Rules and published them in the NN 20/O7. considered "contrary to the common interest", i.e. incompatible with the internal market. The capacity and output reductions agreed by Croatia for its shipbuilding companies represent compensation measures aimed at providing access to the common European market. Therefore, the huge amounts of state aid granted in Croatia in the previous period would not put the national shipyards in a more favourable position compared to other European shipbuilders.

\section{Contributions to the restructuring plan provided} by companies from their own resources are also laid down in the acquis and are envisaged by the Rules on Rescue and Restructuring Aid to range from 25\% (for small enterprises) to 40\% (medium enterprises) and 50\% (large enterprises). The purpose of providing own contribution to the restructuring process by a company is to strictly limit the amount and intensity of state aid, as well as to reduce the use of public funds to a necessary minimum and strengthen the responsibility of companies for restructuring. The Accession Treaty envisages the contribution of own funds to represent $40 \%$ of the total restructuring costs of Croatian shipyards, which classifies them as medium-sized enterprises.

It should be reiterated that, if the obligations laid down in the Accession Treaty are not met, i.e. if the four shipbuilding companies are not privatised under the agreed conditions, the European Commission may, after the accession, order Croatia to recover any rescue or restructuring aid (with compound interest), granted since I March 2006. According to the official CCA data, shipbuilding companies in the periode 2006-Io received HRK IO.2 billion in state aid ${ }^{8}$.

Together with the aid granted in 2011 and 2OI2, which remains to be calculated with compound interest and publicly disclosed by the CCA, the amounts to be recovered by the shipbuilding companies are really huge. This indicates the seriousness of the challenge confronting the Croatian Government and shows how vital it is - after the bankruptcy of Brodogradilište Kraljevica and the signing of the Brodosplit privatisation contract with DIV Group, to accelerate and complete the privatisation of 3. Maj and Brodotrogir shipyards 9 .

It is interesting to recall what Malta and Poland, two new Member States with major shipbuilding industries, agreed in their respective EU Accession Treaties. Malta had

\footnotetext{
8 Source: CCA annual reports.

9 On 20 June 2OI2, the Government of the RC approved the privatisation model of the 3 Maj shipyard, the offer for the purchase of which should be submitted by Uljanik shipyard after its privatisation (through employee share ownership and recapitalisation). The Government also approved the takeover of Brodotrogir shipyard by the company KERMAS energija d.o.o. (http://www.vlada.hr/hr/naslovnica).
} 
two shipyards and shipbuilding constituted the biggest individual industry in the country, characterised by overcapacity, insufficient financing facilities, high labour costs and low productivity levels. In order to restructure its state-owned, loss-making shipyards, Malta agreed upon a transition regime monitored by the Commission, allowing it to grant restructuring aid up to a maximum of EUR 948 million over a period from 2002 to end-2008. Unlike Malta, Poland had a large shipbuilding sector, but it did not negotiate any transitional periods for the application of state aid rules. Instead, Gdynia and Szczecin shipyards were required to finalise their financial and material restructuring plans by 2006 and 2004 (European Commission, 2004).

It should be noted that, once the restructuring and privatisation of shipbuilding companies is complete, Croatia will be allowed to continue granting aid to this sector, in accordance with the European Framework on State Aid to Shipbuilding (see Box). Pursuant to these rules, aid to shipbuilding can be granted in the form of regional aid, aid for innovation and export credits. Generally, however, shipbuilding companies will be supported as any other enterprise, i.e. in accordance with the rules governing other horizontal aid.

\section{New EU rules on state aid to shipbuilding}

The European Commission has adopted a new Framework on State Aid to Shipbuilding (OJ 20II/C 364/o6)) that became applicable on I January 2012 and will expire on 3I December 20I3. Croatia has not yet incorporated the Framework into its legislation. However, it will be obliged to apply it, as part of the EU acquis. The Framework continues to allows aid for innovation in shipbuilding and export crediting, as well as regional aid, but it does not allow closure, employment and development aid, as regulated under the "old" Framework on State Aid to Shipbuilding, because the Commission considers this aid not to be specific to the shipbuilding sector only, and, as such, to be subject to other state aid rules. The Commission envisages that, after 2013, the innovation aid and regional aid to shipbuilding will also be regulated by other rules on horizontal aid.

\section{STEEL}

The Accession Treaty provides that CMC Sisak d.o.o. should reimburse the restructuring aid received by this steel producer in the period from I March 2002 to 28 February 2007, plus compound interest. In case CMC Sisak d.o.o. fails to reimburse the said amount, the Commission shall, upon accession, order Croatia to recover any rescue and restructuring aid granted to this company since I March 2006, with compound interest. ${ }^{\text {IO }}$

An abstract of Annex IX to the Accession Treaty.
After 2007, two Croatian steel producers were privatised: Željezara Split d.o.o. was acquired by Polish Zlomrex, and the rolling mill Valjaonica cijevi Sisak d.o.o. was bought by Commercial Metals International AG, Baar, Switzerland. At the end of 2008, production declined in both steel mills, mainly due to the global market situation. As a result, both companies stopped the production - Željezara Split in April 2009 (Vlada RH, 20IO) and CMC Sisak d.o.o. in October 20II (European Commission, 2012a).

Under the Accession Treaty, state aid in the amount of HRK I9 million, received by CMC Sisak d.o.o. in the period from I March 2002 to 28 February 2007 has to be reimbursed. The company recognised the debt which remained unpaid by end-February 2012 (European Commission, 20I2a). In June 2OI2, CMC Sisak d.o.o. sold the steel mill to the Italian company Danieli, which is expected to help in regulating debt repayment ${ }^{\text {II }}$. Upon Croatia's accession, if CMC Sisak d.o.o. fails to reimburse the entire amount of debt, the Commission will order Croatia to recover any rescue and restructuring aid granted to this company since I March 2006, with compound interest. Aid received by the steel mill Željezara Split will also have to be reimbursed. In May 2OII, CCA ordered that Željezara Split should reimburse aid in the amount of HRK 289 million with accrued interest, because, due to bankruptcy, the company was incapable of meeting the conditions relating to investment, realisation of profit, etc., which gave rise to irregularities in the application of state aid regulations ${ }^{12}$.

According to the CCA data (20II), with the exception of HRK 2.2 million, paid by the Croatian Privatisation Fund in 2009 for minimum wages of employees, after the Polish investor had withdrawn from Željezara Split, no new aid was granted to iron and steel producing companies during 2008 and 2010.

Among the EU-I2 Member States, Poland and Czech Republic have particularly strong steel industries.

Therefore, these countries' accession treaties provided for transitional arrangements. In slightly more than two years after the accession (by 3I December 2006) they had to complete the restructuring of their steel sectors. Subject to closely monitored conditions, the Commission allowed these countries the granting of state aid in the period of $1997-2003$ in the maximum amounts of EUR 4I3 million (Czech Republic) and EUR 769 million (Poland) (European Commission, 2004).

II http://www.tportal.hr/biznis/gospodarstvo/I97696/Talijani-kupili-zeljezaru-Sisak.html

I2 A Decision issued by the Croatian Competition Agency, NN 58/II. 
Despite the uncertain fate of the Croatian iron and steel industry, future investors can still count on state aid pursuant to the Rules on State Aid to the Steel Sector (NN I34/o8), based on the State aid Act, i.e. the acquis commmunautaire.

\section{EXISTING AID}

Under the Accession Treaty, the following aid schemes put into effect in Croatia before the date of accession and applicable after that date are regarded upon accession as existing aid:

\section{- aid measures put into effect before I March 2002;}

- aid measures listed in the Appendix to Annex IV of the Accession Treaty (aid granted under the free zones, Croatian Radiotelevision and scientific activity and higher education acts, aid granted to Osijek and Rijeka airports, aid to Rockwool Adriatic d.o.o. and aid under the Book Publishing Financing Programme);

- aid measures assessed by the CCA before the date of accession and found to be compatible with the acquis, and to which the Commission did not raise any objections.

All aid measures still applicable after the date of accession, which do not belong to the above mentioned three categories, shall be considered as new aid ${ }^{13}$.

It is important to distinguish between the existing and new aid. Aid that is regarded as "existing aid" under the Accession Treaty shall be subject to examination by the Commission even after the EU accession. Should any such aid measures be found incompatible with the acquis, the Commission may order that they be amended or abolished, but it cannot require reimbursement of granted aid. In contrast to this, all other aid considered as "new aid" can also be examined by the Commission, but the Commission can order reimbursement of the granted aid. A list attached to Annex IV to the Accession Treaty sets out seven state aid measures that shall continue to be applied after Croatia's accession to the EU and shall be considered as "existing aid". Croatia has applied for another four measures, compatible with the acquis to be included in this list, and to be considered as "existing aid" upon accession (European Commission, 2OI2a). More specifically, it is in the interest of every future Member State to have as many as possible state aid measures considered as "existing aid", because, should such aid be found incompatible with the acquis, it can be amended or abolished, but the recovery of aid amounts already granted cannot be required. For example, during the accession process of EU-Io Member States, the largest number of existing state aid measures were approved to Czech Republic (I20) and the smallest to Estonia (only 3). These

I3 An abstract of Annex IV to the Accession Treaty. measures were incorporated in the countries' respective Accession Treaties (European Commission, 2004).

The EU has imposed strong external conditionality on the new Member States with respect to state aid, as this area is considered crucial for avoiding competition distortions and preserving the common market (Mulas-Granados, Koranchelian and Segura-Ubiergo, 2008). The external conditionality exerts decisive pressure on accession candidates to change their state aid measures. This is suggested by movements in and the structure of state aid in EU-I2, where the share of aid in GDP decreased while allocations for horizontal objectives increased in almost all the Member States ${ }^{14}$. In Croatia, too, external conditionality, i.e. pressures from the EU, prompted long-delayed changes in state aid policy. The restructuring and privatisation of the steel, shipbuilding and railway sectors accelerated with the approaching of the date of accession, by which these processes should be completed.

\section{STATE AID IN GROATIA AFTER EU AGGESSION}

Croatia's pre-accession experience in developing a state aid system was similar to the experiences of other candidate countries that joined the EU in 2004 and 2007. During the pre-accession period, these countries were supposed to incorporate state aid control systems into their legislation, similar to those in the EU, in order to ensure the approval, control, but also the reimbursement of unlawful aid. Another requirement was to establish an authority responsible for the implementation of that system. Croatia has complied with these requirements by adopting the relevant legislation; it established a Croatian Competition Agency and transposed the rules on state aid, incorporated in the EU acquis, into its national legislation. These rules have been applied for a long number of years, i.e. since the signing of the Stabilisation and Association Agreement in 200I. Ever since that date, the CCA has gradually, persistently and consistently applied these rules to both undertakings receiving aid and public authorities that grant it.

Upon accession, the assessment of the lawfulness of state aid, its surveillance and recovery will be transferred to the exclusive jurisdiction of the European Commission, the only authority competent for making decisions on state aid for all Member States. This will also change the role of the CCA, which will, as in all other Member States, become a subsidiary body of the European Commission for the registration and notification of state aid, data collection, keeping the register of state aid, providing information, rendering assistance to aid providers, etc. However, the transfer of competence for state aid matters to

I4 For more, see Jović (2OI2). 
the European Commission does not mean that Croatia will not be allowed to grant aid. It will continue to grant it, as do all the other EU Member States. Providing financial support to enterprises is not prohibited in the EU, and is subject to the same rules as those already implemented by the CCA. The only difference is that, after I July 20I3, these rules will be enforced by the European Commission. Croatia will have to make certain administrative, technical and personnel adjustments to this effect in order to enable the CCA to provide adequate assistance to the Commission.

The Commission is preparing substantial changes in the state aid scheme to become effective by end-2013, i.e. shortly upon Croatia's accession. These changes are aimed at modernising state aid and are part of a broader EU strategy to stimulate economic growth, target aid at market failures and promote rational use of public resources. The Commission will examine, streamline and amend most aid allocation rules, particularly those relating to rescue and restructuring, environmental protection and regional aid, and will facilitate the decisionmaking processes. The CCA must closely monitor these changes and make the necessary administrative arrangements for participating in their implementation (European Commission, 20I2b).

After the EU accession, the size and structure of state aid will increasingly resemble those of the current Member States. The share of aid in GDP is expected to trend downwards, state aid will be less and better targeted, and sectoral aid will be reduced. This means that state aid will be focused on the so-called horizontal objectives, such as research and development, environmental protection, employment, regional development, etc. A reduction is expected primarily in sectoral aid to companies in difficulties, which distorts competition and favours one, usually less successful firm, over others, where the aid granted to such a firm only postpones its inevitable exit from the market.

As the date of Croatia's EU accession approaches, external conditionality intensifies, accelerating changes in the area of state aid: the restructuring and privatisation of the shipbuilding sector, the largest recipient of aid, must be completed by the accession date (otherwise, shipyards will have to reimburse the aid received since I March 2006); due to bankruptcy proceedings in the Split and Sisak steel mills, aid to the steel sector was completely suspended after 2008, and the two steel producers were ordered to reimburse the unlawfully granted aid; arrangements are being made for the restructuring of Croatian Railways, the largest state aid recipient in the transport sector, and it is planned to be carried out during the cur- rent year, because the accession will lead to the liberalisation of the railway market and entry of other operators into the national market ${ }^{\mathrm{t}}$. The Ministry of Finance has not planned any increases in subsidies in the national budget $^{16}$ - in 20I4, they will be held at the same level as in 2013 (Ministry of Finance of the RC, 2012). Nevertheless, there are no discernible moves towards horizontal aid, as no programmes were submitted for approval to the CCA during 2011 that would suggest any significant increase in aid for horizontal objectives (CCA, 2OII).

Croatia's EU accession will bring about changes in the national state aid policy. Consequently, the "old" model based on "providing selective aid to sectors in difficulties, to the detriment of others which produce goods and services of high value added or develop new forms of entrepreneurship" (CCA, 2OII) will become unsustainable. This should be accepted, as soon as possible, by all economic agents: public institutions, trade unions, managers and employees, but also the general public. The time has come when scarce public resources must finally start to be used rationally.

\section{LITERATURE:}

CGA, 20II. Annual Report on State Aid for 20Io. Available from: [http://www.aztn.hr/uploads/documents/eng /documents/AR/Annual_report_State_aid_2OIO_ ENG6.4.pdf].

European Commission, 2004. State Aid Scoreboard autumn 2004 update. Brussels, I6. II. 2004. COM (2004)750 final. Available from: [http://ec.europa.eu/ competition/state_aid/studies_reports/archive/2004_autumn_en.pdf].

European Commission, 2012a. Monitoring report on Croatia's accession preparations. Brussels, April 24, 20I2. Available from: [http://ec.europa.eu/commission_2OIO-OI4/fule/docs/news/2OI2O424_report_fi nal.pdf].

European Commission, 20I2b. State Aid Modernisation. Available from: [http://ec.europa.eu/competition/ state_aid/modernisation/index_en.html].

European Commission, 2012c. Scoreboard - Data on state aid expenditure. Available from: [http://ec.europa. eu/competition/state_aid/studies_reports/expenditure.html].

Jović, I., 2012. "EUı2: State Aid Before and After EU Accession". Newsleter, No. 69. Available from: [http:// www.ijf.hr/upload/files/file/ENG/newsletter/69. pdf].

I5 Based on the statement made by minister Hajdaš Dončić on Io July 2012 (Žabec, 2OI2).

I6 Subsidies represent the most important type of state aid, and they accounted for $72,6 \%$ of total aid in 2010 (CCA, 2OII). 
Kesner-Škreb, M., 2012. "Eight Findings About the 2012 State Aid in Croatia”. Press Releases, No. 37. Available from: [http://www.ijf.hr/upload/files/file/osvrti/37. pdf].

Ministry of Finance of RG, 2012. Državni proračun Republike Hrvatske za 20I2. godinu i projekcije za 20I3. 20I4. Available from: [http://www.mfi n.hr/hr/drzavniproracun-20I2-godina].

Mulas-Granados, G., Koranchelian, T. and SeguraUbiergo, A., 2008. "Reforming Government Subsidies in the New Member States of the European Union". IMF Working Paper, WP/o8/165. Washington: International Monetary Fund.
Rješenje Agencije za zaštitu tržišnog natjecanja, NN 58/II. Zagreb: Narodne novine.

Government of RG, 20Io. Pregovaračka stajališta Republike Hrvatske za međuvladinu konferenciju o pristupanju Republike Hrvatske Europskoj uniji za poglavlje 8. “Tržišno natjecanje”. Zagreb, April I, 20Io. Available from: [http://www.mvep.hr/custompages/static/hrv /files/pregovori/4/o8.pdf].

Žabec, K., 2012. "HŽ kreće u restrukturiranje: Do kraja godine 2700 radnika ostat će bez posla!" Jutarnji list, July IO, 20I2. Available from: [ht p://www.jutarnji.hr/ restrukturiranje-u-hz-holdingu--do-kraja-godine2700-radnika-ostat-ce-bez-posla/IO40I6o/]. 